\title{
Assessment of Surface Water Resources in Case of Muger Sub Basin, Ethiopia
}

\author{
Dereje Adeba, Shimelis Tafese \\ College of Engineering and Technology, Wollega University, Nekemte, Ethiopia \\ Email address: \\ Mo_dereje2018@yahoo.com (D. Adeba), Shimelistafese2016@gmail.com (S. Tafese)
}

To cite this article:

Dereje Adeba, Shimelis Tafese. Assessment of Surface Water Resources in Case of Muger Sub Basin, Ethiopia. Journal of Energy and Natural Resources. Vol. 10, No. 3, 2021, pp. 53-64. doi: 10.11648/j.jenr.20211003.11

Received: May 20, 2021; Accepted: July 1, 2021; Published: July 13, 2021

\begin{abstract}
Water resources assessment (WRA) is the process of measuring, collecting and analysing relevant parameters on the quantity and quality of water resources for the purposes of a better development and management of water resources. The aim of this research is Assessment of Surface Water Resource in Case of Muger Sub Basin in Ethiopia. The future possible local climate variables are extracted from Abbay basin RCM and then the bias-corrected with observed meteorological variables which are then used as input to the soil and water assessment tool (SWAT) model as climate data, in addition to climate data soil data, land use land cover, slope of the sub basin and weather Generator together are used to simulate future water yield of Muger sub-basin. Soil and Water Assessment Tool (SWAT) was adopted to perform runoff simulation. The good performance of the SWAT model was confirmed, with a Nash-Sutcliffe efficiency (NSE) and determination coefficients $\left(\mathrm{R}^{2}\right)$ of 0.76 and 0.99 respectively during calibration for monthly runoff, Nash-Sutcliffe efficiency (NSE) 0.63 and determination coefficients $\left(\mathrm{R}^{2}\right) 0.99$ respectively during validation for monthly runoff. The variation of precipitation in Muger sub basin decreased by (2010-2023), (2024-2037) and (2038-2050) from base period (1996-2009) will be $0.36 \%, 1.076 \%$ and 1.74\% respectively, Maximum Temperature in sub basin increase from base period (1996-2009) by $0.55 \%, 2.32 \%$ and $4.6 \%$ and also minimum temperature in Muger sub basin increase by (2010-2023), (2024-2037) and (2038-2050) from base period (1996-2009) was 0.83\%, 2.80 and 8.54\% respectively. From this study, it was observed that due to climate change Average annual water yieldin Mugersub basinin (1996-2009), (2010-2023), (2024-2037), (2038-2050) is $4634.07 \mathrm{Mm}^{3}, 4525.92 \mathrm{Mm}^{3}, 4456.20 \mathrm{Mm}^{3}$ and $4411.89 \mathrm{Mm}^{3}$ respectively. Generally as Temperature increase in the study area the amount of rainfall decreases which directly affect the amount of water yield.
\end{abstract}

Keywords: Climate Change, Muger Sub-basin, SWAT, SWAT-CUP

\section{Introduction}

Climate is the average behavior of the atmosphere over long periods of time. Even though the annual periodicity in weather patterns, the climate is subject to changes. During the past few decades, it has become apparent that human activities such as fossil fuel burning and land-use change (e.g., deforestation) have considerably increased the atmospheric concentrations of greenhouse gases (GHGs). As a result, changes in climate have started and are expected to continue for centuries/millennia until GHGs concentrations stabilize (if at all possible) [2, 8]. Scientists agreed that climate change has adverse impacts on the socio-economic development of all nations. But the degree of impact will vary across nations. It is expected that changes in the earth's climate will hit developing countries like Ethiopia first and hardest because their economies are strongly dependent on crude forms of natural resources and economic structure is less flexible to adjust to such drastic changes [7]. According to the Intergovernmental Panel on Climate Change report, by 2100 global average temperature would rise between 1.4 and $5.8^{\circ} \mathrm{C}$ and precipitation would vary up to $\pm 20 \%$ from the 1990 level [7].

Upper Blue Nile Basin is one of the largest basins in Ethiopia with high population pressure, degradation of land and highly dependent on an agricultural economy and sensitive to climatic variations [4]. The increase in population growth, economic development, and climate change have been proven by [7]. Muger Sub-basin is one of the primary sub-basins of Upper Blue Nile Basin which experiences severe famine due to recurrent drought and the lack of advanced water infrastructure to use the full potential 
of available water resources.

In climate change impact studies, hydrologic models are required to simulate sub-grid scale phenomena, and such hydrologic models require input data at a similar scale. These data are generally provided by converting the RCM outputs into a reliable regional hydrologic time series at the selected watershed scale. The methods used to convert RCM outputs into local meteorological variables are usually referred to as 'downscaling' techniques [5].

\section{Hydrological Component of SWAT}

Water balance is the driving force behind everything that

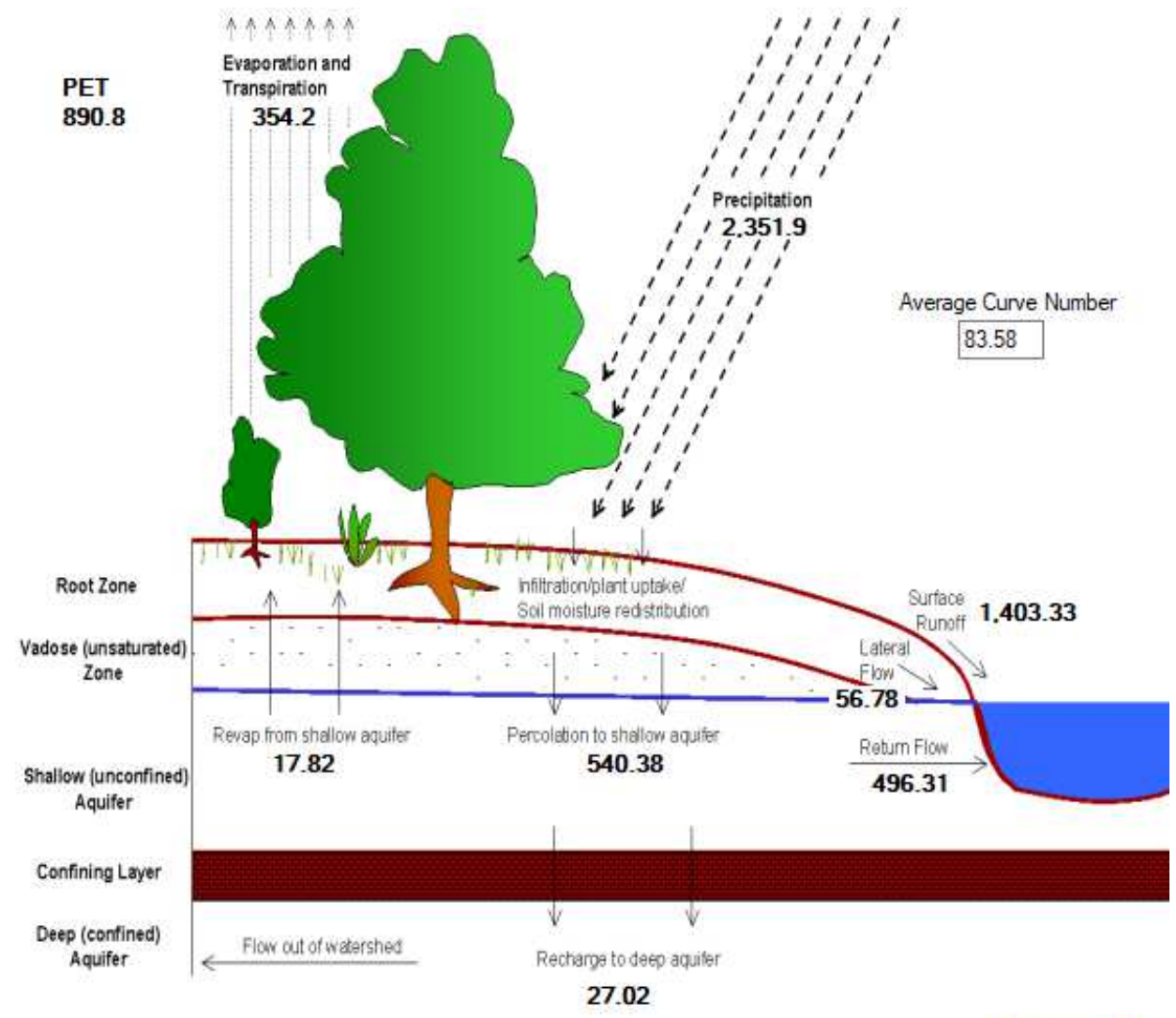

Figure 1. Hydrological Cycle During Baseline Scenario (1996-2009).

\subsection{Surface Runoff}

SCS curve number method estimates the amount of runoff based on land use, soil type, and antecedent moisture condition. Therefore, the SCS curve number method is simple, widely used and efficient for determining the approximate amount of runoff from a rainfall event under varying land use and soil types [14]. The 1972 SCS curve number equation (3) is used in SWATmodel

$$
Q_{\text {Surf }}=\frac{\left(R_{\text {day }}-I_{a}\right)^{2}}{\left(p-I_{a}\right)+s}
$$

Where

$\mathrm{Q}_{\text {surf: }}$ is the accumulated rainfall excess ( $\mathrm{mm} /$ day);

$\mathrm{R}_{\text {day }}$ : is the rainfall depth for the day ( $\mathrm{mm} /$ day) happens in the watershed. The simulation of the hydrology of a watershed is done in two separate divisions [14]. The first is the land phase process of the hydrological cycle that controls the fluxes of water, sediment, nutrient and pesticide loadings to the main channel in each sub-basin. Hydrological components which are simulated in this process include precipitation, canopy storage, infiltration, Evapotranspiration, lateral flow, surface runoff, and return flow.

The second division is the water or routing phase of the hydrological cycle which is the movement of water, nutrients, sediment, and pesticides through the channel network of the watershed into the outlet.
27.02

$\mathrm{I}_{\mathrm{a}}$ : is the initial abstraction which includes surface storage, infiltration, and infiltration prior to runoff ( $\mathrm{mm} /$ day) and

$\mathrm{S}$ : is the retention parameter ( $\mathrm{mm} /$ day).

The retention parameter varies spatially due to changes in soils, land use management and slope, and temporarily due to changes in the soil water content. The retention parameter is defined as in equation (2)

$$
S=25.4\left[\frac{100}{C N}-10\right]
$$

Where

$\mathrm{CN}$ : is the curve number for the day.

The curve number is based on the areas, hydrologic soil group, land use, and hydrologic condition. The initial abstractions, 
$\mathrm{I}_{\mathrm{a}}$ : is commonly approximated as $0.2 \mathrm{~S}$ and Equation (1) becomes:

$$
Q_{\text {Surf }}=\frac{\left(R_{\text {day-0.2s }}\right)^{2}}{R_{\text {day }+0.8 s}}
$$

Runoff will occur when $\mathrm{P}>\mathrm{I}_{\mathrm{a}}$.

Most of the water in the earth's surface is removed by Evapotranspiration. Roughly $62 \%$ of the precipitation that falls on the continents is removed by evapotranspiration [14]. Hence accurate estimation of Evapotranspiration is vital in the assessment of water resources [6]. Three methods for estimating potential Evapotranspiration (PET) are provided in SWAT. These are Priestly-Taylor, Penman-Monteith, and Hargreaves methods [9, 16]. For this research due to the availability of the data, the Penman-Monteith method was used for the determination of the potential Evapotranspiration.

\subsection{Flow Routing Phase}

The available storage method was used for this study. The method was developed by Williams in 1969 [9]. The equation of the available storage Routing is given by:

$$
\Delta \text { Vstored }=\text { Vin }- \text { Vout }
$$

1) $\Delta V$ stored changes in the volume of storage during the time step $\left(\mathrm{m}^{3}\right.$ water $)$

2) Vin is the volume of inflow during the time step $\left(\mathrm{m}^{3}\right.$ water) and,

3) Vout is the volume of outflow during time step $\left(\mathrm{m}^{3}\right.$ water)

\subsection{Data Acquisitions}

For this study, various data are required that includes topographic data (DEM), land use and land cover data, soil data, daily data of climatic variables (daily data of precipitation, maximum and minimum temperature, relative humidity, wind speed, and solar radiation). The land use land cover was obtained from satellite GLCF website. Soil, DEM and hydrological data were collected from the MOWIE. The climatic data were obtained from the national metrological agency of Ethiopia (NMAE).

\section{Location}

Muger sub-basin has an area of $7558.479 \mathrm{~km}^{2}$. The major river in the basin is Muger River. Muger River flows from the southeast of the basin into Abbay River [14].

Where

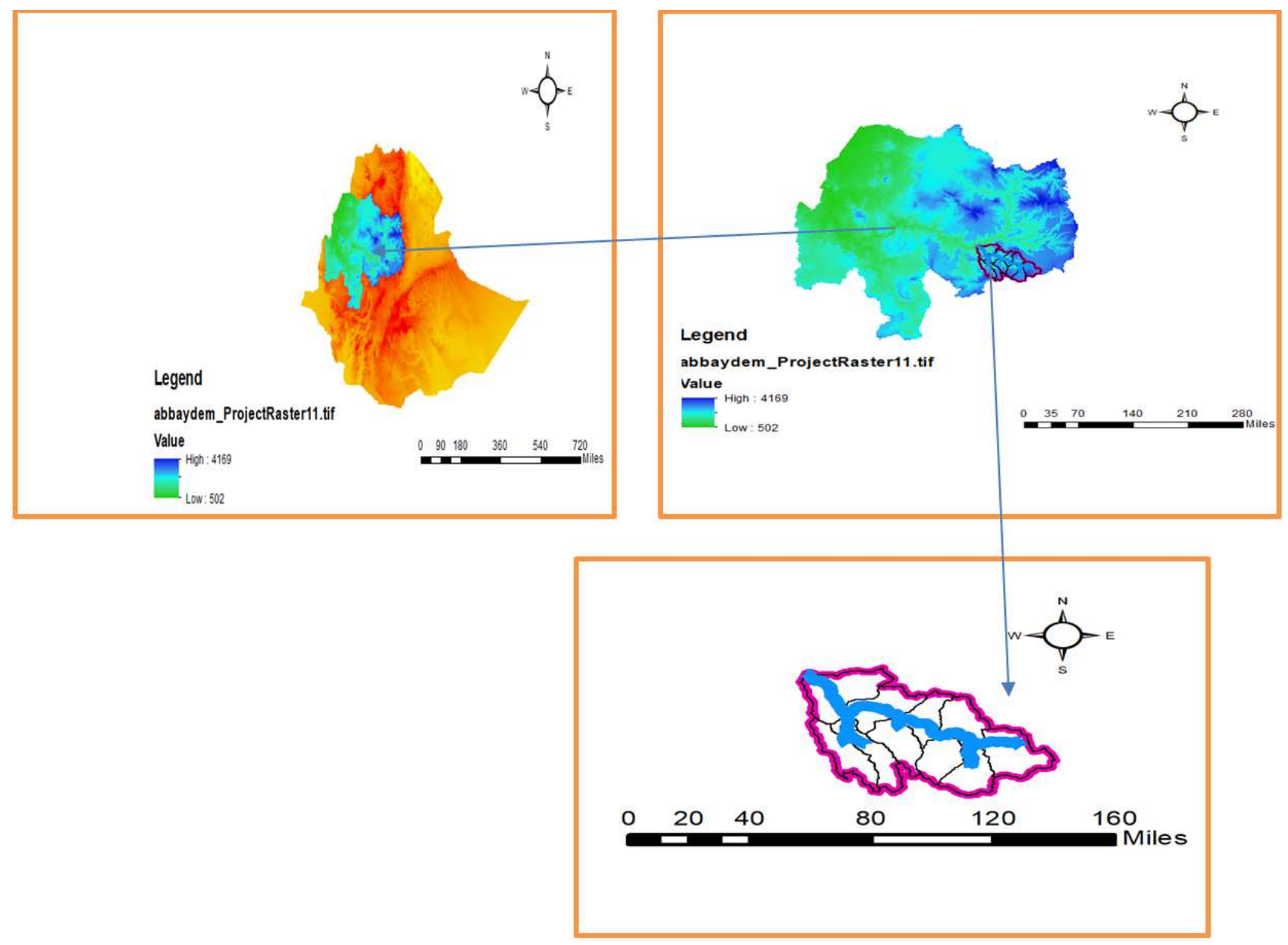

Figure 2. Location of muger subbasin. 


\subsection{Topography}

The altitude in Muger sub-basin ranges between 940 masl and 3446 masl. The highlands in the eastern and southern part of the sub-basin are higher in altitude, greater than 2600 meters up to 3446 meters. The lowlands along the Muger River have lower altitude less than 1700 masl [1]

\subsection{Climate}

The sub-basin has an annual rainfall ranging between 833 $\mathrm{mm}$ and $1326 \mathrm{~mm}$. Lower annual rainfall from $833 \mathrm{~mm}$ up to $1000 \mathrm{~mm}$ along the river and lowlands, and higher rainfall greater than $1000 \mathrm{~mm}$ is observed in the highlands. The annual maximum and minimum temperature in the sub-basin varies between $16^{\circ} \mathrm{C}-31.5^{\circ} \mathrm{C}$ and $13^{\circ} \mathrm{C}-16.5^{\circ} \mathrm{C}$ respectively. Potential Evapotranspiration (PET) in the sub-basin is between $1215 \mathrm{~mm}$ and $1970 \mathrm{~mm}$ per year. PET is higher greater than $1800 \mathrm{~mm} / \mathrm{yr}$, along the river where there is high temperature. The highlands in the eastern part of the basin show lower PET, less than $1450 \mathrm{~mm} / \mathrm{yr}$ [3]

\subsection{Soil}

Major and dominant soil types identified in the sub-basin are Luvisols, Leptosols, Vertisols, Fluvisols, Haplic Alisols, Haplic Nitisols, Eutric Vertisols, and Alisols. The most dominant soil type is Luvisols. The second dominant soil is Fluvisols.

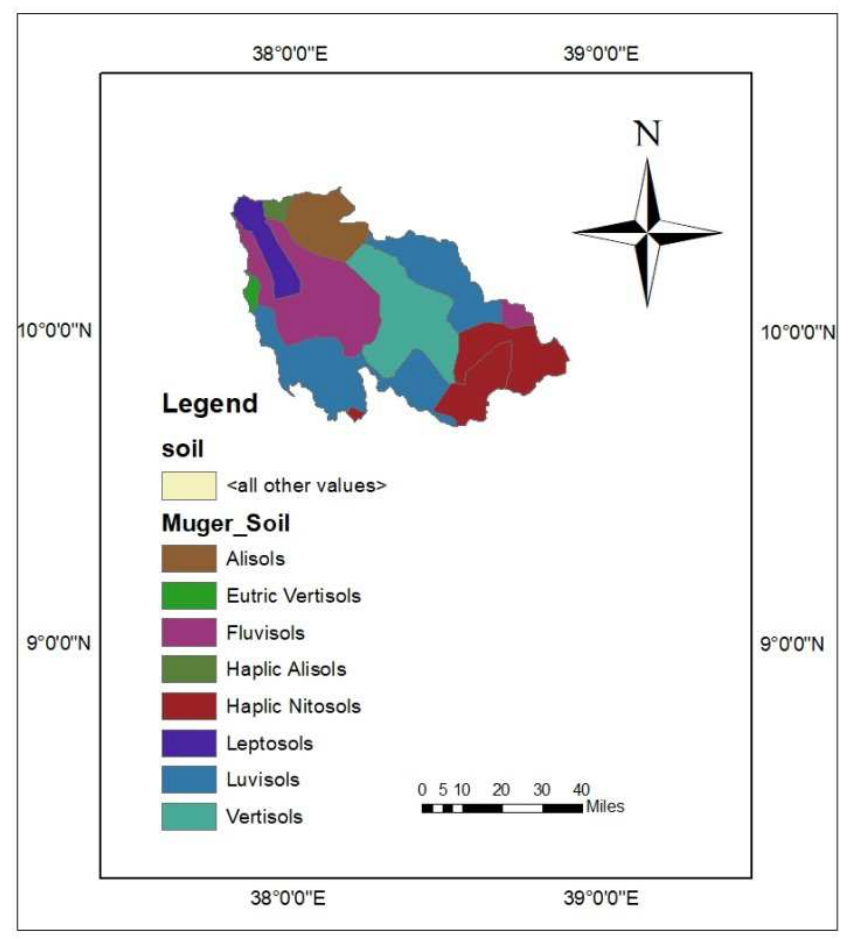

Figure 3. Major soil types in muger sub-basin.

\section{Land Cover and Land Use}

The land use in Muger sub-basin is dominated by Agro- pastoral and Agriculture. Pastoral land is also observed in some parts of the sub-basin. The agro-ecological zones are characterized by tepid to cool moist highlands. The northwestern part of the lowlands is hot to warm moist lowlands.

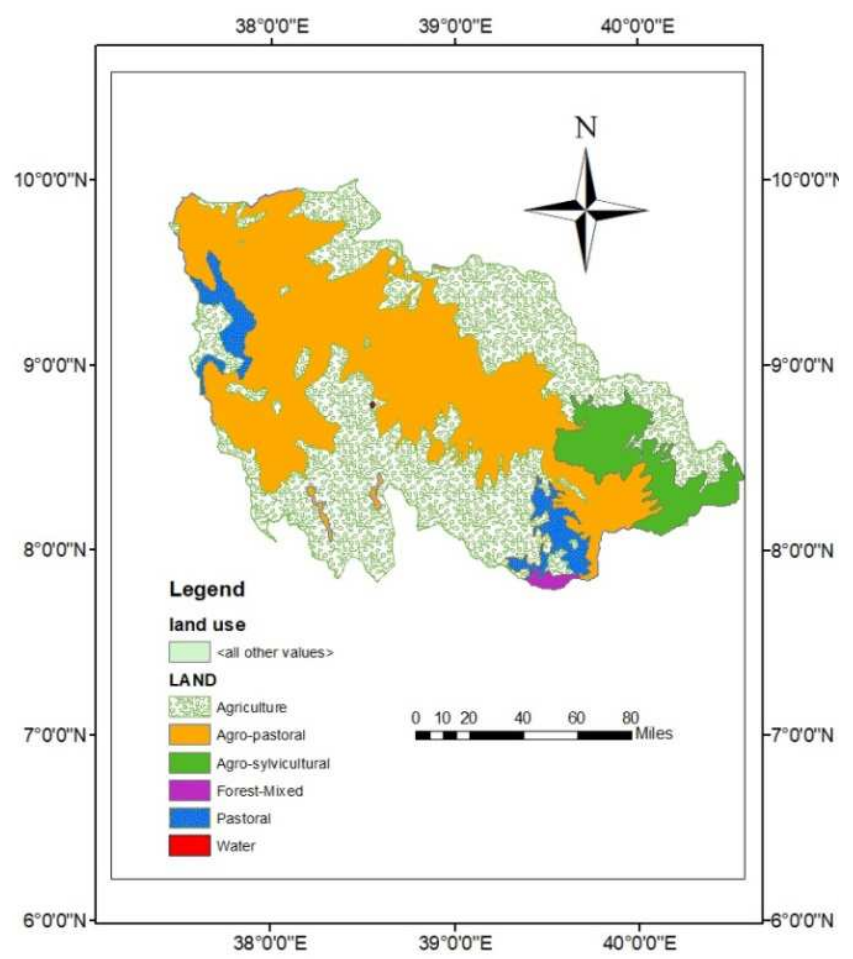

Figure 4. Land cover land use map.

Table 1. Land use categories in the sub basin.

\begin{tabular}{lllll}
\hline S. No & land use & & & \\
\cline { 2 - 5 } & Categories & Class & $\begin{array}{l}\text { Area } \\
\left(\mathbf{k m}^{\mathbf{2}}\right)\end{array}$ & $\begin{array}{l}\text { Watershed } \\
\text { in } \mathbf{( \% )}\end{array}$ \\
\hline 1 & Agricultural Land-Generic & AGRL & 3360.99 & 44.47 \\
2 & Agricultural Land-Row Crops & AGRR & 3272.85 & 43.30 \\
3 & Pasture & PAST & 337.81 & 4.47 \\
4 & Agricultural Land-Close-grown & AGRC & 552.03 & 7.30 \\
5 & Water & WATR & 0.93 & 0.01 \\
6 & Forest-Mixed & FRST & 33.87 & 0.45 \\
\hline
\end{tabular}

\subsection{Meteorological Data}

Meteorological data was required for two purposes in this study. First, the data was used for downscaling the RCM data using Statistical Downscaling Model (SDSM) [13]. Second, the data was used as input to the SWAT model in hydrological model development. Based on these objectives, the meteorological data required for this study were collected from the Ethiopian National Meteorological Services Agency which found in Addis Ababa capital city of Ethiopia. The meteorological variables collected vary from station to station depending on the class of the stations. The daily meteorological data collected are precipitation, maximum temperature, minimum temperature, relative humidity, wind speed and sunshine hours. 
Table 2. List of the station name, location, and meteorological variables.

\begin{tabular}{llllll}
\hline Station Name & Longitude & Latitude & Elevation Period & Length \\
\hline Debrabirhan & 39.50 & 9.63 & 2750 & $1985-2016$ & 32 \\
A. A. Observator & 38.75 & 9.02 & 2386 & $1985-2017$ & 33 \\
Sululta & 38.73 & 9.18 & 2610 & $1985-2014$ & 29 \\
Muger & 38.34 & 9.46 & 2553 & $1985-2010$ & 25 \\
Chancho & 38.75 & 9.32 & 2640 & $1985-2009$ & 24 \\
Gerbaguracha & 38.42 & 9.82 & 2560 & $1985-2011$ & 26 \\
Fitche & 38.73 & 9.77 & 2784 & $1985-2016$ & 31 \\
\hline
\end{tabular}

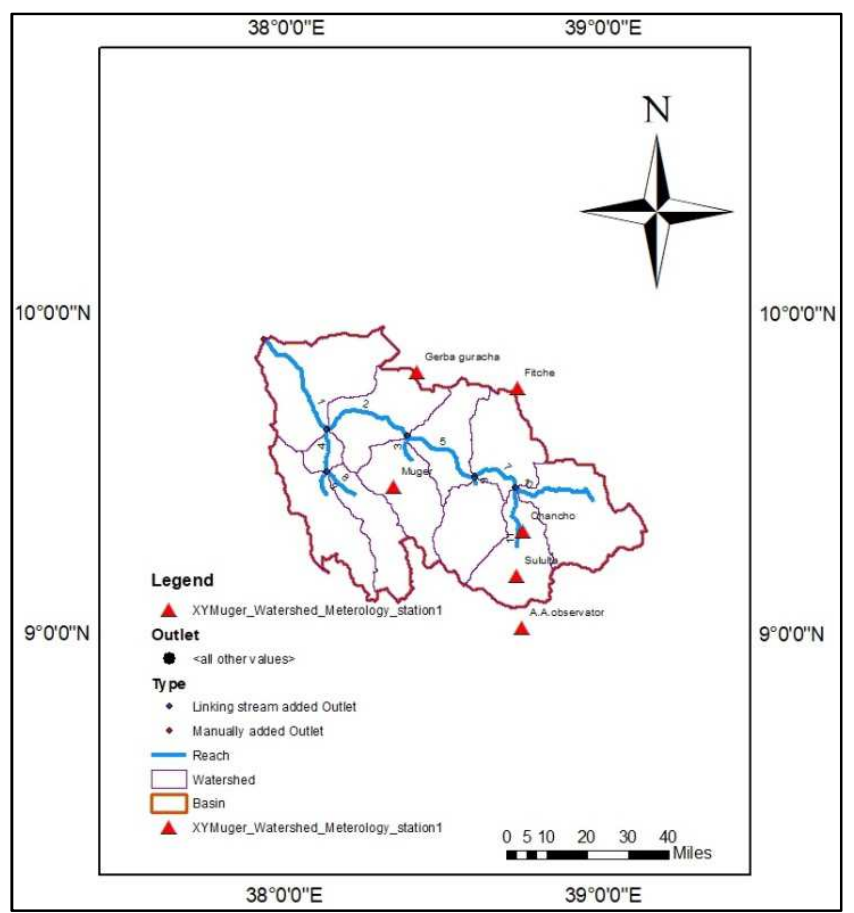

Figure 5. Muger watershed meterology station.

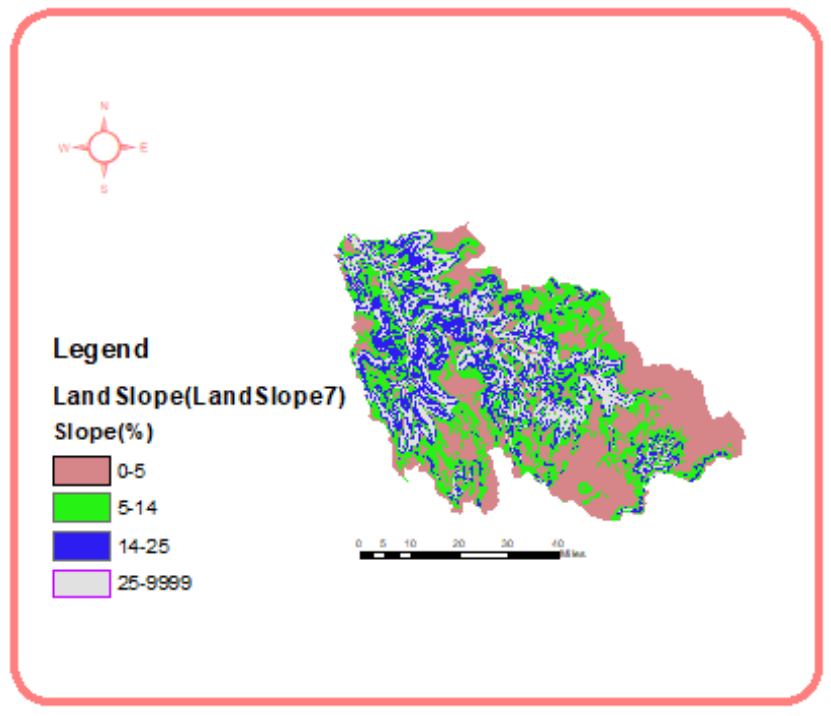

Figure 6. Slope classification.

\subsection{Hydrological Data}

The office responsible for collecting and disseminating hydrological data is the Hydrology Department in the Ministry of Water Resources (MoWR). The hydrological data was required for performing sensitivity analysis, calibration, and validation of the Hydrological model. Daily data of Muger river at one gauging stations Aleltu at Muketuri were collected. The records of discharge used for this study is fifteen years daily data from thirten years data for Aleltu subcatchment at Muketuri from 1996-2009.

\subsection{Catchment Data Analysis}

Catchment topography, soil and land cover patterns govern the spatial distribution of preciptation. Subsequently, in response to watershed climate, topography, and land cover conditions affect runoff production behavior within a catchment. Boundary and the stream networks were delineated from a 30x30 m grid cell digital elevation model (DEM) using hydrologic functions of ArcGIS.

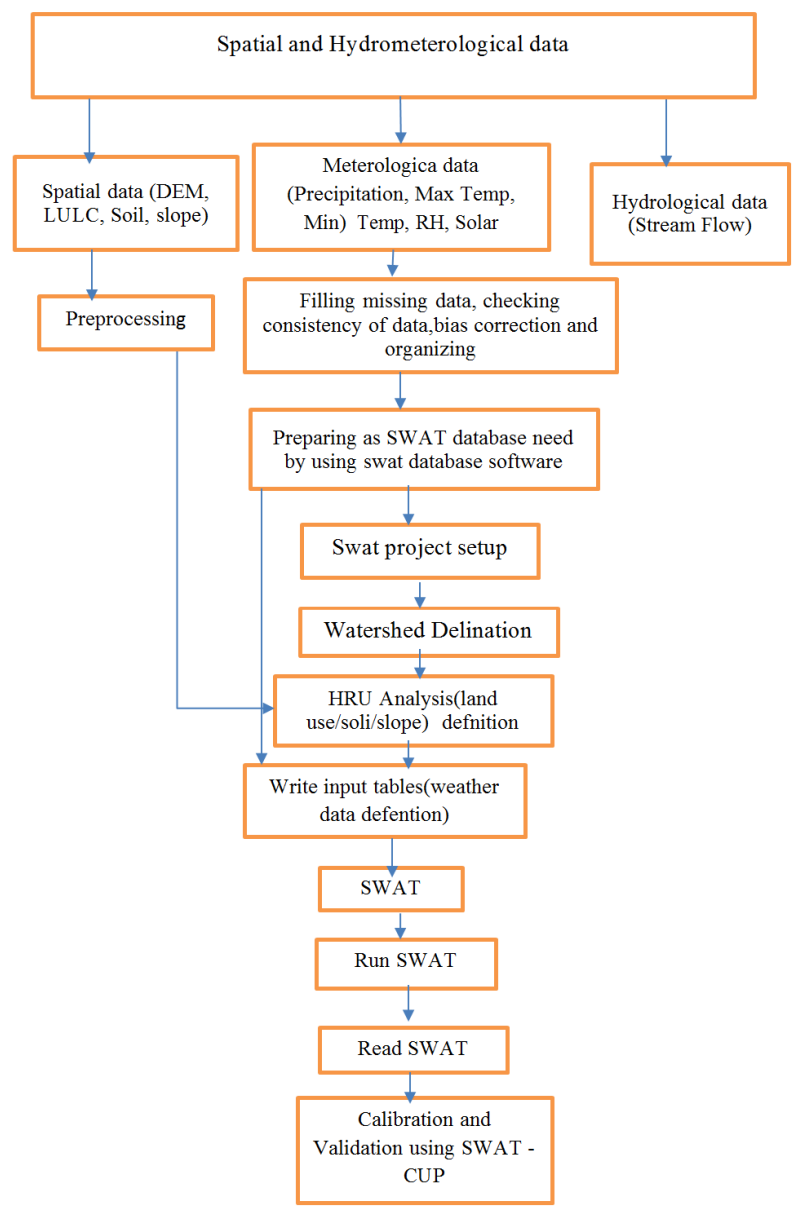

Figure 7. General Framework of SWAT model and its setup.

\subsection{Elevation and Slope}

The elevation information of Muger is obtained from DEM using ArcGIS10.3. The lowest elevation of Muger is $940 \mathrm{~m}$ amsl at its outlet (gauging station) and its peak reaches an elevation of $3446 \mathrm{~m}$ amsl in the south easternmost part of the catchment.

The land surface slope of Muger catchment was computed using ArcGIS10.3. To get insight on the variation of catchment responses owing to slope difference between the watersheds, slope of each watershed where reclassified to gentle $(0-5 \%)$, 
steep $(5-14 \%)$ and excessive $(14-25 \%)$ as it shown in figure 6. The excessive slope area of the watersheds lies in the south and decreases northwards. A considerable part of Muger has gentle slopes since the ground slope is responsible for controlling the infiltration process.

\section{Model Performance Evaluation}

Model evaluation is an essential measure to verify the strength of the model. In this study, four model evaluation methods were used, which were Nash-Sutcliffe efficiency (NSE), coefficient of determination $\left(\mathrm{R}^{2}\right)$

$$
N S E=1-\frac{\sum_{i=1}^{n}\left(X_{i}^{o b s}-X_{i}^{\text {sim }}\right)^{2}}{\sum_{i=1}^{n}\left(X_{i}^{o b s}-X^{\text {mean }}\right)^{2}}
$$

where,

$\mathrm{X}_{\mathrm{i}}^{\text {obs }}=$ observed variable (flow in $\mathrm{m}^{3} \mathrm{~s}^{-1}$ or sediment concentration in $\mathrm{mg}^{-1}$ ).

$\mathrm{X}_{\mathrm{i}}^{\mathrm{sim}}=$ simulated variable (flow in $\mathrm{m}^{3} \mathrm{~s}^{-1}$ or sediment concentration in $\mathrm{mg}^{-1}$ ).
$\mathrm{X}^{\text {mean }}=$ mean of $\mathrm{n}$ values

$\mathrm{n}=$ number of observations

The $\mathrm{R}^{2}$ is calculated using the following equation:

$$
R^{2}=\frac{\sum\left[X_{i}-X_{a v}\right] *\left[Y_{i}-Y_{a v}\right]}{\sqrt{\sum\left[X_{i}-X_{a v}\right]^{2} * \sqrt{\sum\left[Y_{i}-Y_{a v}\right]^{2}}}}
$$

where,

$\mathrm{Xi}$ - measured value $\left(\mathrm{m}^{3} / \mathrm{s}\right)$

$\mathrm{Xav}$ - average measured value $\left(\mathrm{m}^{3} / \mathrm{s}\right)$

$\mathrm{Yi}$ - simulated value $\left(\mathrm{m}^{3} / \mathrm{s}\right)$ and

Yav - average simulated value $\left(\mathrm{m}^{3} / \mathrm{s}\right)$

\section{Result and Discussion}

\subsection{Sensitivity Analysis}

Sensitivity analysis of simulated streamflow for the subbasin was performed using the monthly observed flow data for identifying the most sensitive parameter and for further calibration of the simulated streamflow.

\begin{tabular}{|c|c|c|c|c|c|}
\hline Parameter Name & Description & Rank & Min-Value & Max-Value & Fitted Value \\
\hline CH_N2.rte & Manning's value for the main channel & 7 & 0 & 0.3 & 0.1123 \\
\hline CH_K2.rte & Effective hydraulic conductivity of main channel & 6 & 5 & 130 & 126.785 \\
\hline ALPHA_BNK & & 5 & 0 & 1 & 0.93 \\
\hline ESCO.hru & Soil evaporation compensation factor & 4 & 0.8 & 1 & 0.924 \\
\hline HRU SLP.hru & & 3 & 0 & 0.2 & 0.192 \\
\hline CN2.mgt & Moisture condition II curve number & 2 & 35 & 98 & 79.84 \\
\hline GW_DELAY.hru & Ground delay ((days) & 1 & 30 & 450 & 146.72 \\
\hline
\end{tabular}

Table 3. Sensitive parameters and their sensitivity rank.

From those parameters Groundwater delay (GW_DELAY), SCS runoff curve number (CN2), Average slope steepness (HRU_SLP), Soil evaporation compensation factor (ESCO), Baseflow alpha factor for bank storage (ALPHA_BNK), Channel effective hydraulic conductivity
(CH_K2) and Manning's n value for main channel (CH_N2) are sensitive parameters and ranked from 1 up to 7 respectively. The remaining parameters were not considered during model calibration, as the model simulation result was not sensitive to the sub-basin.

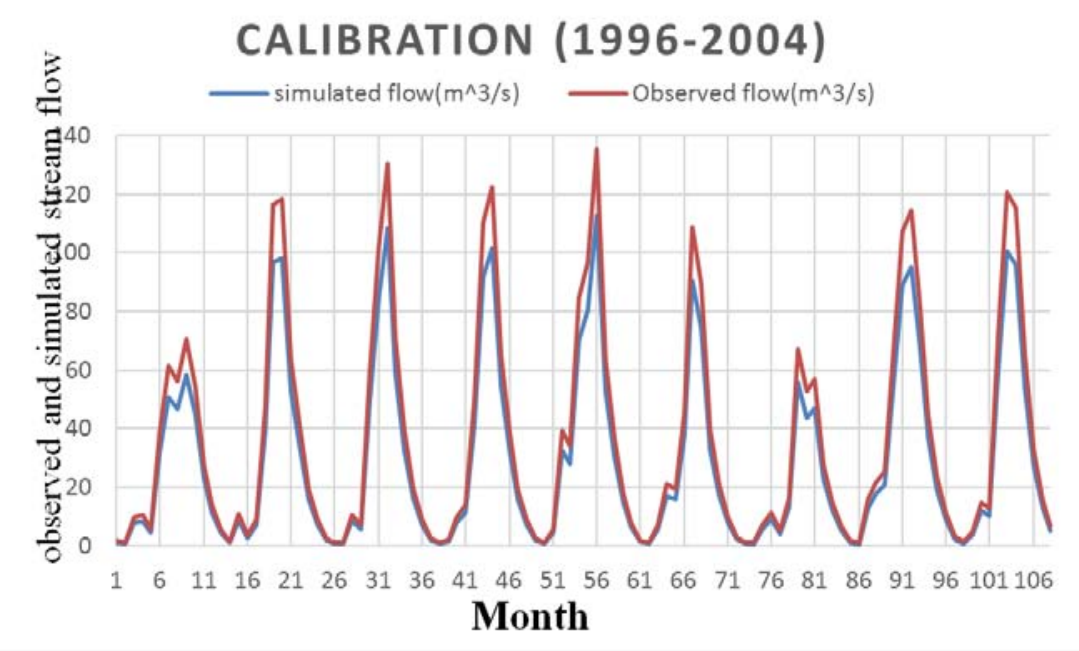

Figure 8. Calibration of streamflow from (1996-2004). 


\subsection{Model Calibration}

The model calibration show a good agreement between observed and simulated monthly stream flow figure 8 with Nash-Sutcliffe efficiency (NSE) value of 0.76 and coefficient of determination $\left(\mathrm{R}^{2}\right)$ value of 0.99 .

\subsection{Model Validation}

The model validation show a good agreement between simulated and measured monthly stream flow (figure 9) with the Nash-Sutcliffe efficiency (NSE) value of 0.63 and coefficient of determination $\left(\mathrm{R}^{2}\right)$ value of 0.99 .

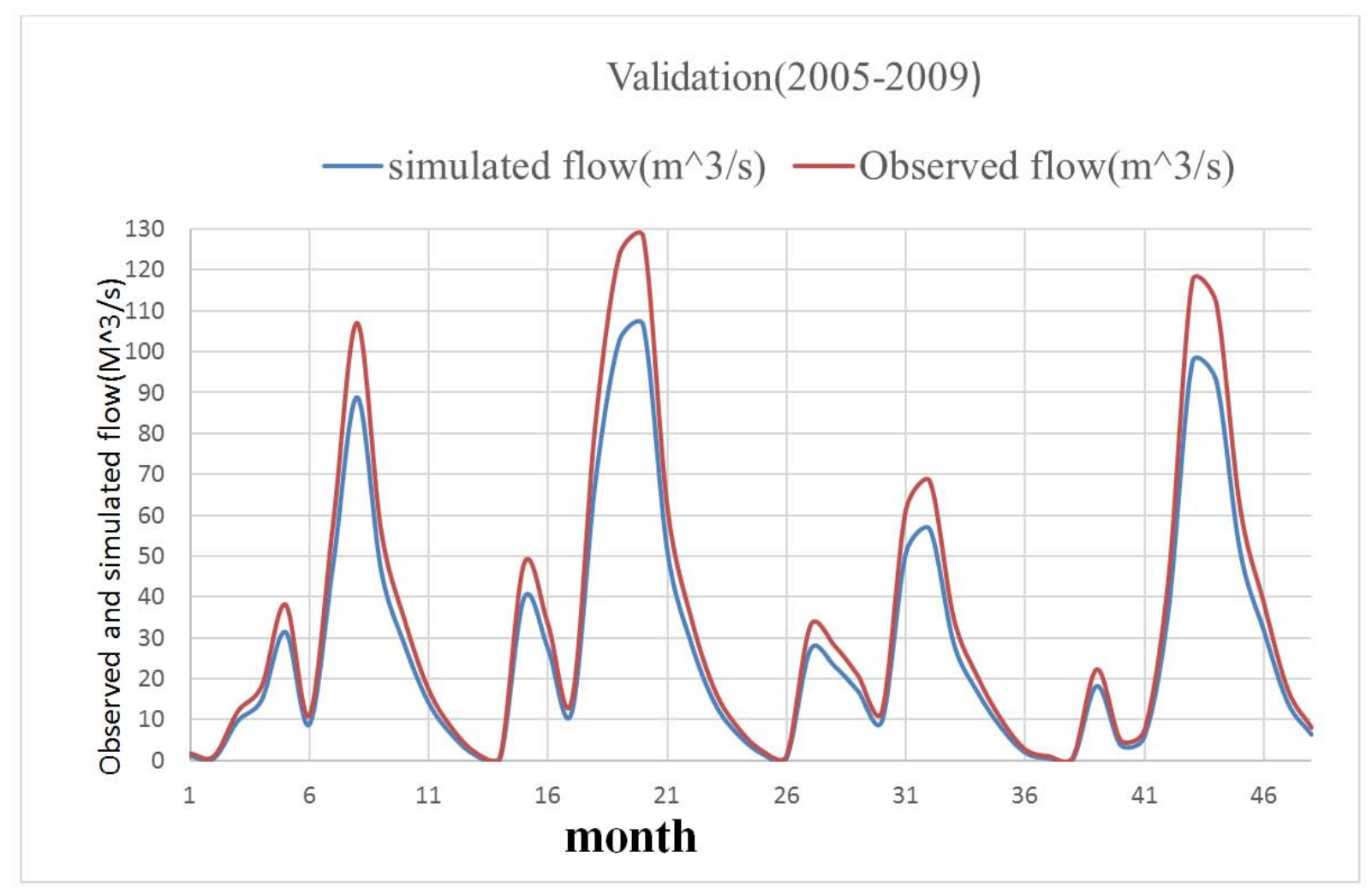

Figure 9. Validation of streamflow from (2005-2009).

Table 4. Average monthly streamflow for calibration and validation.

\begin{tabular}{|c|c|c|c|c|c|}
\hline & Season & Observed flow $\left(\mathrm{M}^{3} / \mathrm{s}\right)$ & Simulated flow $\left(\mathrm{M}^{3} / \mathbf{s}\right)$ & $\mathbf{R}^{2}$ & Ens \\
\hline \multirow{5}{*}{$\begin{array}{l}\text { Calibration } \\
(1996-2004)\end{array}$} & DJF (Belg) & 15.934 & 14.74 & \multirow{5}{*}{0.99} & \multirow{5}{*}{0.76} \\
\hline & MAM (Bega) & 11.92 & 11.10 & & \\
\hline & JJA (kiremt) & 51.48 & 50.87 & & \\
\hline & SON (Tsedey) & 43.93 & 42.90 & & \\
\hline & Annually & 30.82 & 29.90 & & \\
\hline \multirow{5}{*}{$\begin{array}{l}\text { During Validation } \\
(2005-2009)\end{array}$} & DJF (Belg) & 14.86 & 14.08 & \multirow{5}{*}{0.99} & \multirow{5}{*}{0.63} \\
\hline & MAM (Bega) & 9.52 & 9.09 & & \\
\hline & JJA (kiremt) & 54.00 & 52.22 & & \\
\hline & SON (Tsedey) & 54.15 & 53.55 & & \\
\hline & Annually & 33.13 & 32.24 & & \\
\hline
\end{tabular}

Different studies that were conducted in the lower Blue Nile basin also showed a similar result. For example, [6] reported that SWAT model showed a good match between the measured and simulated flow of Didessa Sub-basin both in calibration and validation periods with $(\mathrm{NSE}=0.76$ and $\mathrm{R}^{2}=0.8$ ) and $\left(\mathrm{NSE}=0.7\right.$ and $\left.\mathrm{R}^{2}=0.79\right)$, respectively. Through modeling upper Blue Nile basin of the Lake Tana basin, indicated that the average monthly flow simulated with SWAT model was reasonably accurate with
$\mathrm{NSE}=0.81$ and $\mathrm{R}^{2}=0.85$ for calibration and $\mathrm{NSE}=0.79$ and $\mathrm{R}^{2}=0.80$ for validation periods $[10,11]$. This indicates that SWAT can give sufficiently reasonable results in the upper Blue Nile basin and hence the model can be used in this Muger sub-basin. The following figure shows the scatter plots of observed and simulated value for both calibration and validation (Figures 10 and 11 below). This shows a good linear correlation between observed and simulated values. 


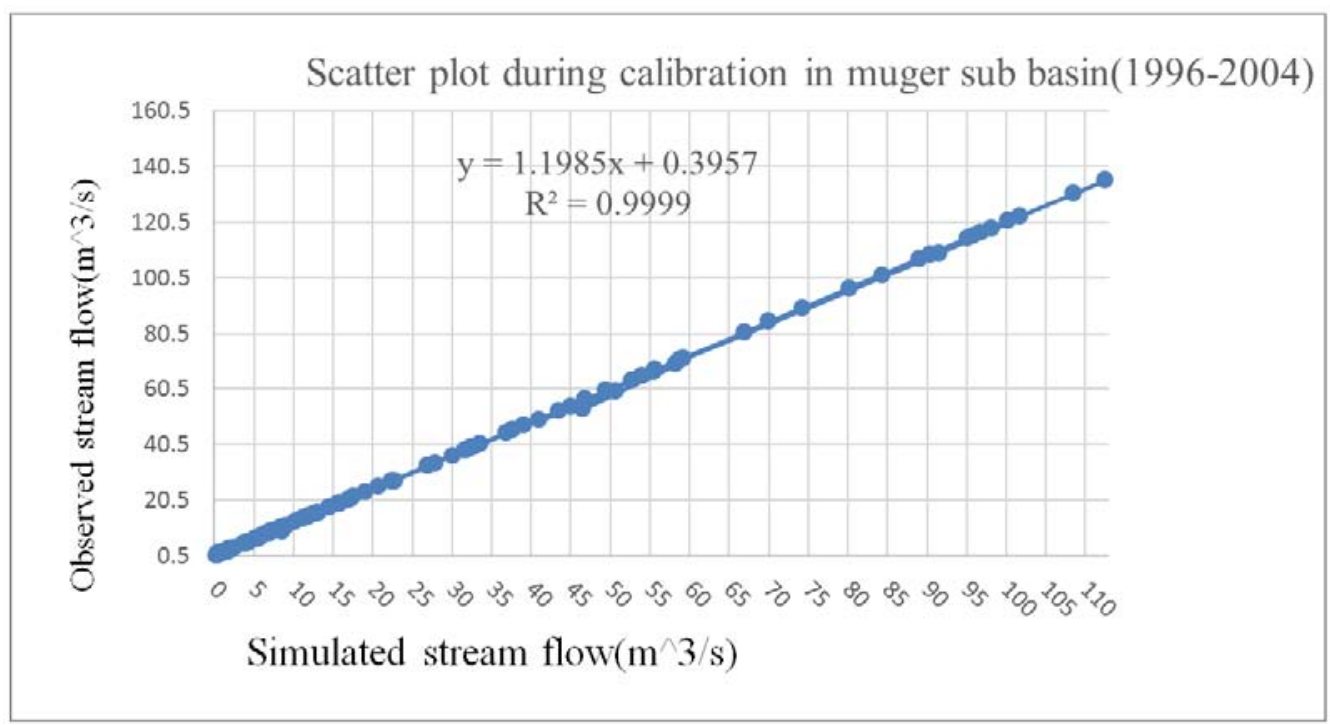

Figure 10. Fitted line between observed and simulated streamflow for calibration.

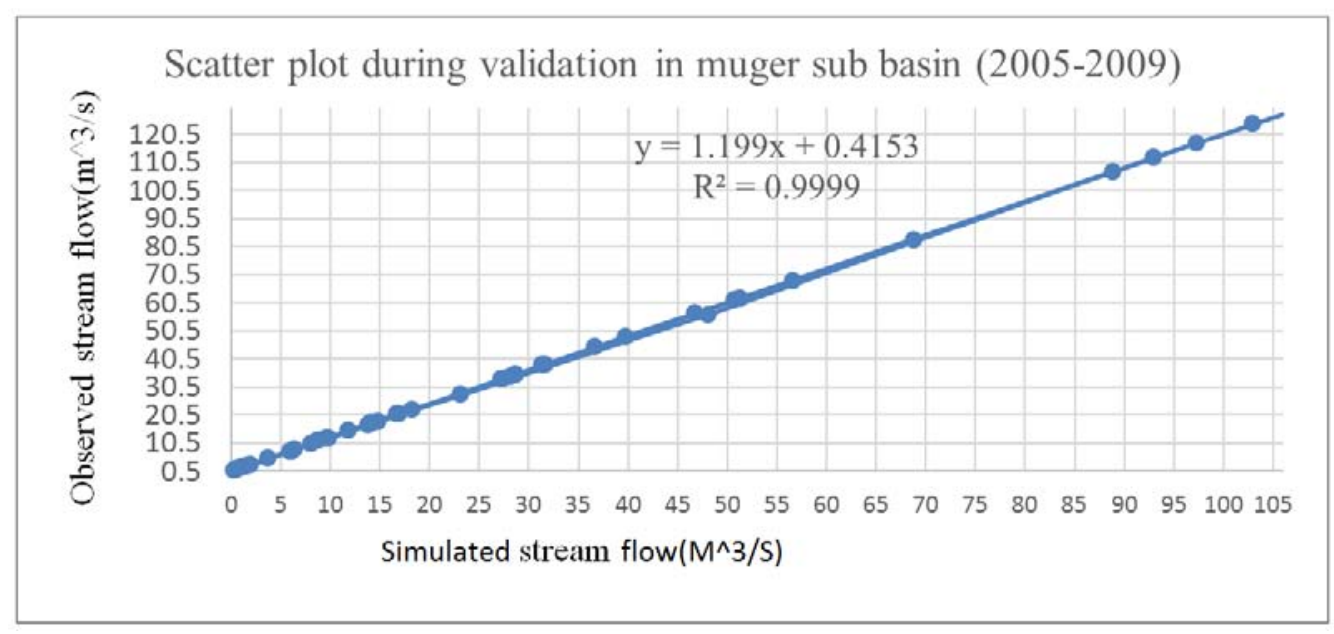

Figure 11. Fitted Line Between observed and simulated streamflow for validation.

\subsection{Climate Change Impact Analysis}

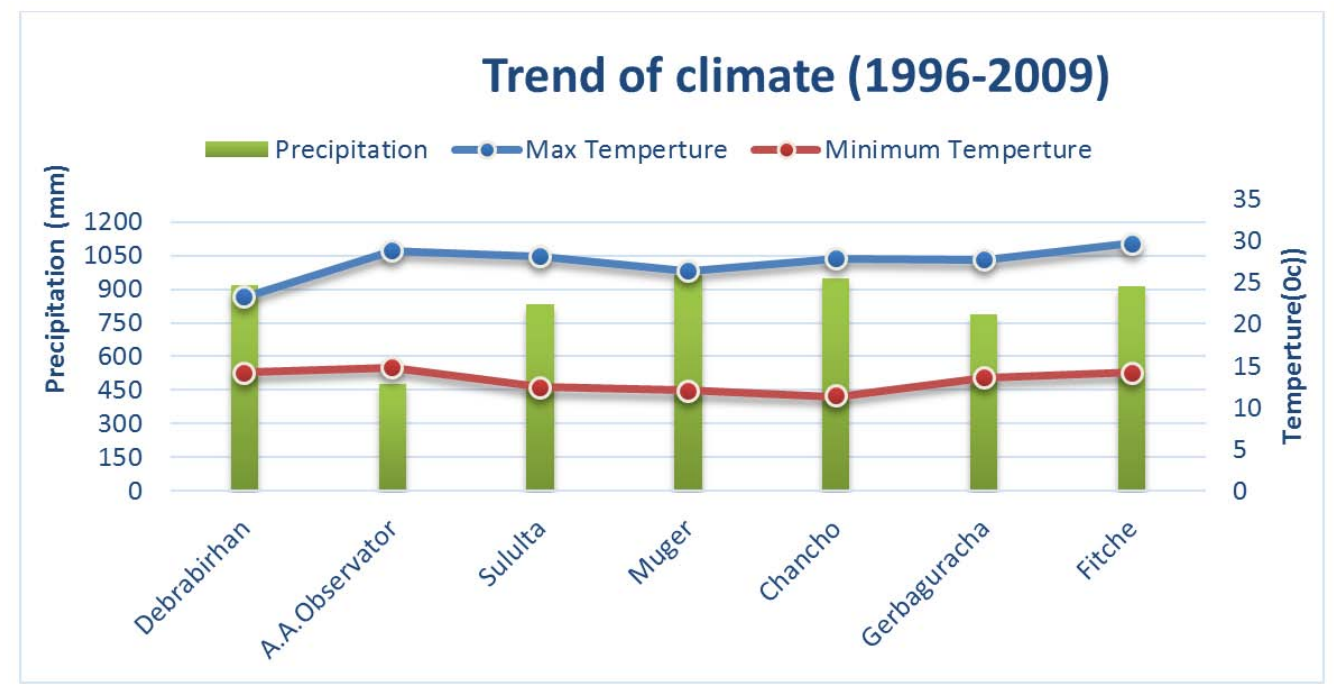

Figure 12. Annual climate of Muger watershed (1996-2009). 


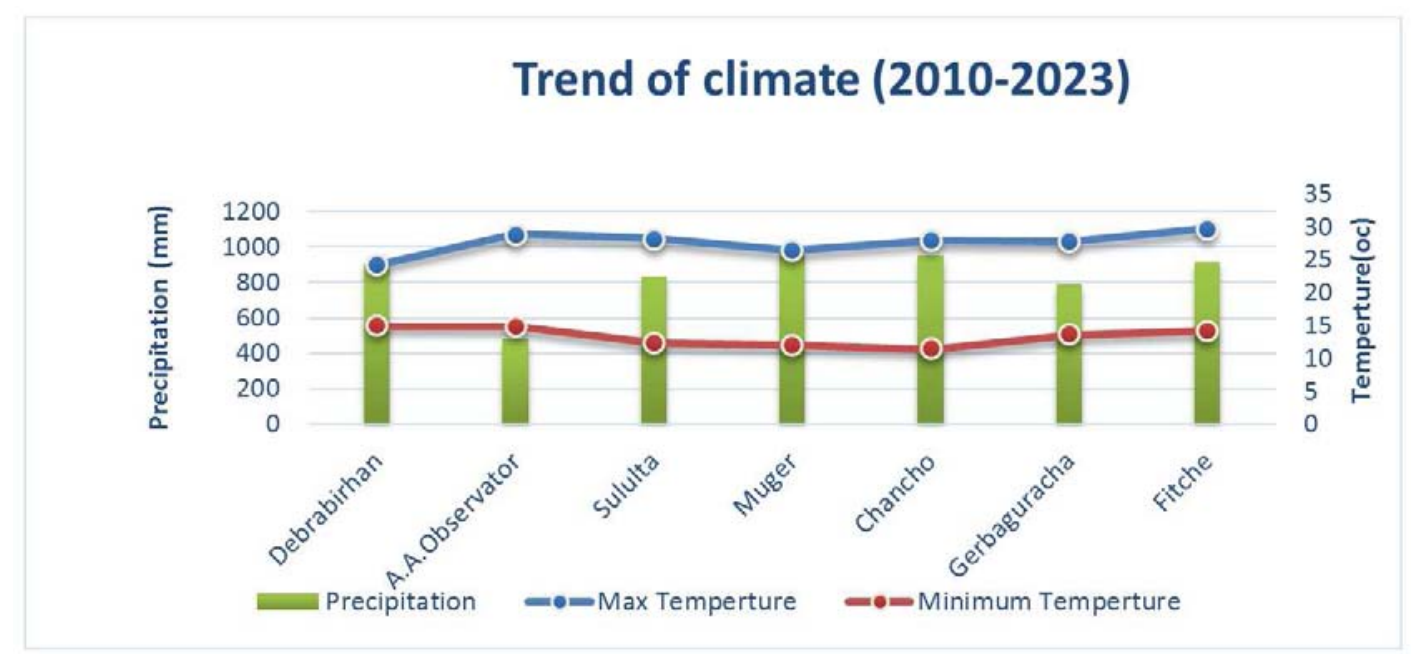

Figure 13. Annual climate of Muger watershed (2010-2023).

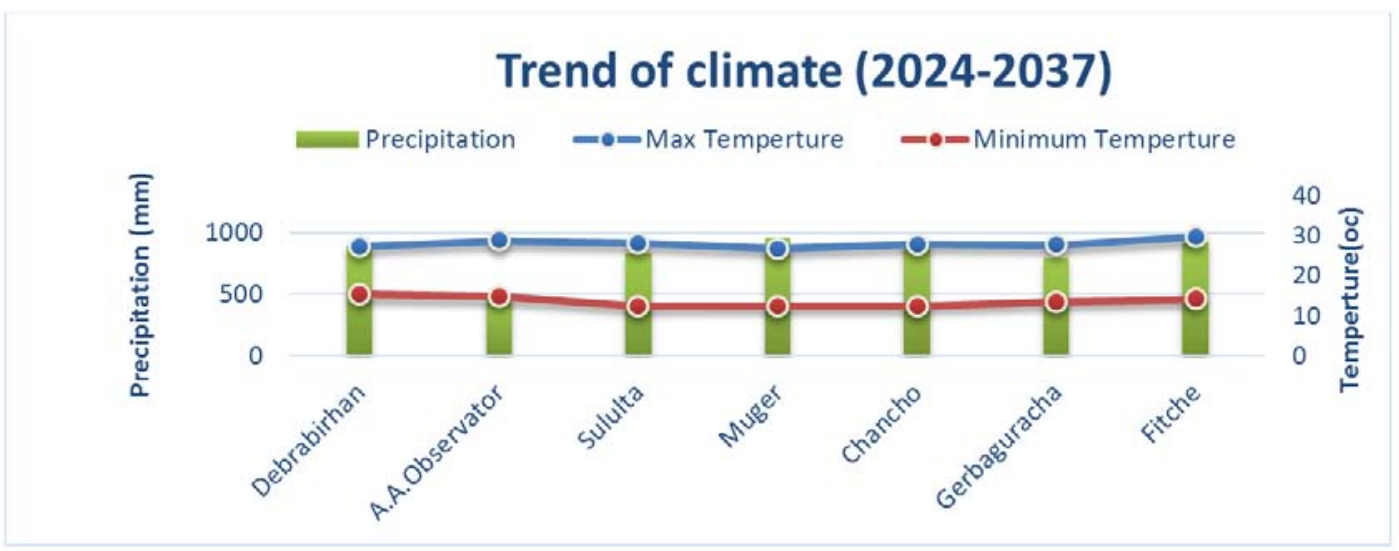

Figure 14. Annual climate of Muger watershed (2024-2037).

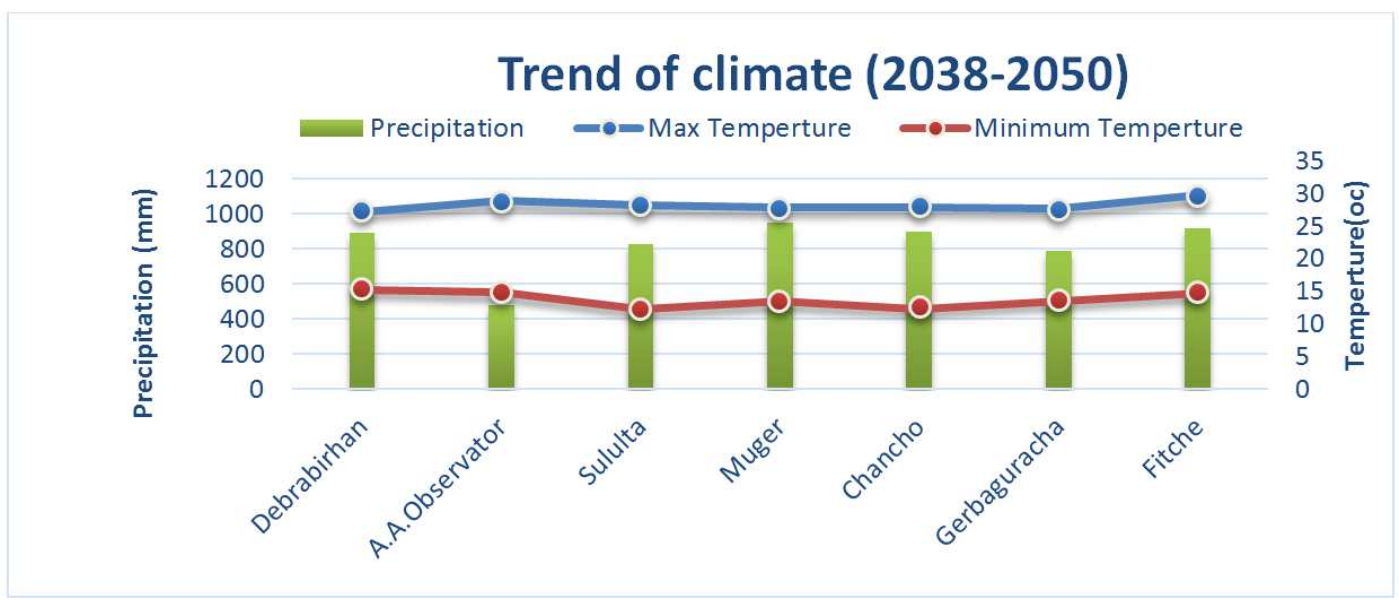

Figure 15. Annual climate of Muger watershed (2038-2050).

Generally the variation of precipitation in Muger subbasin decreased by (2010-2023), (2024-2037) and (20382050) from base period (1996-2009) was 0.36\%, $1.076 \%$ and $1.74 \%$ respectively, Maximum Temperature in subbasin increase from base period by $0.55 \%, 2.32 \%$ and $4.6 \%$ and also minimum temperature in Muger sub-basin increased by (2010-2023), (2024-2037) and (2038-2050) from base period (1996-2009) was $0.83 \%, 2.80$ and $8.54 \%$ respectively.

The effect of climate change on average annual surface runoff of Muger sub-basin shown that surface runoff will decrease due to climate change of the (2010-2023), (20242037) and (2038-2050) from the baseline period (1996-2009) by $3.43 \mathrm{~m}^{3} / \mathrm{s}, 5.64 \mathrm{~m}^{3} / \mathrm{s}$, and $7.05 \mathrm{~m}^{3} / \mathrm{s}$ respectively. 


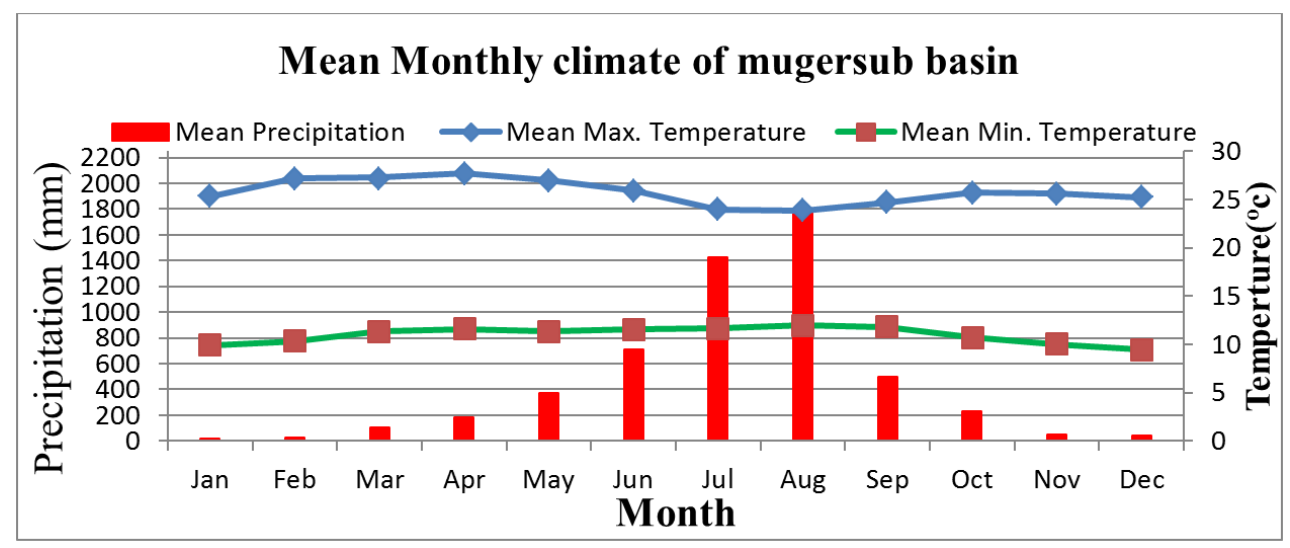

Figure 16. Mean monthly climate of muger sub-basin.

From figure 16 above the maximum mean monthly precipitation in the study area was observed in June, July, and August respectively. In those months the maximum temperature decreases relative to other months because in those months is known as rainy season called "kiremt".

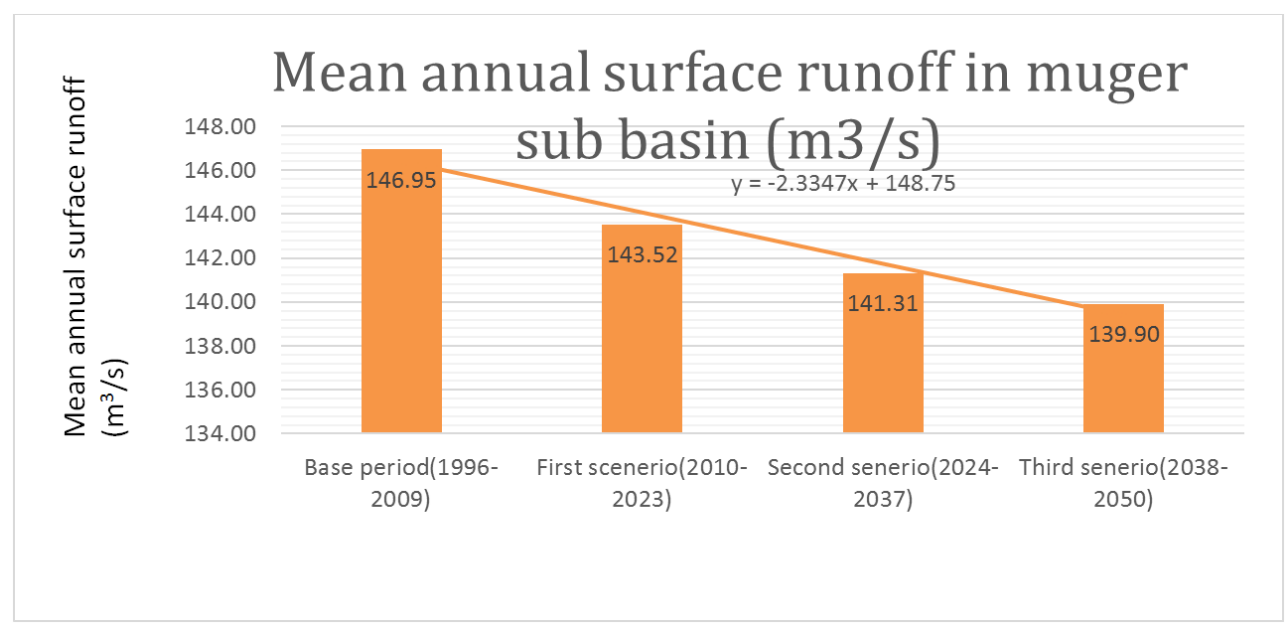

Figure 17. Mean annual surface runoff change due to climate change.

The effect of climate change on average annual surface runoff of Muger sub-basin shown that surface runoff will decrease due to climate change of the (2010-2023), (2024-2037) and (2038-2050) from the baseline period (1996-2009) by $3.43 \mathrm{~m}^{3} / \mathrm{s}$, $5.64 \mathrm{~m}^{3} / \mathrm{s}$, and $7.05 \mathrm{~m}^{3} / \mathrm{s}$ respectively.

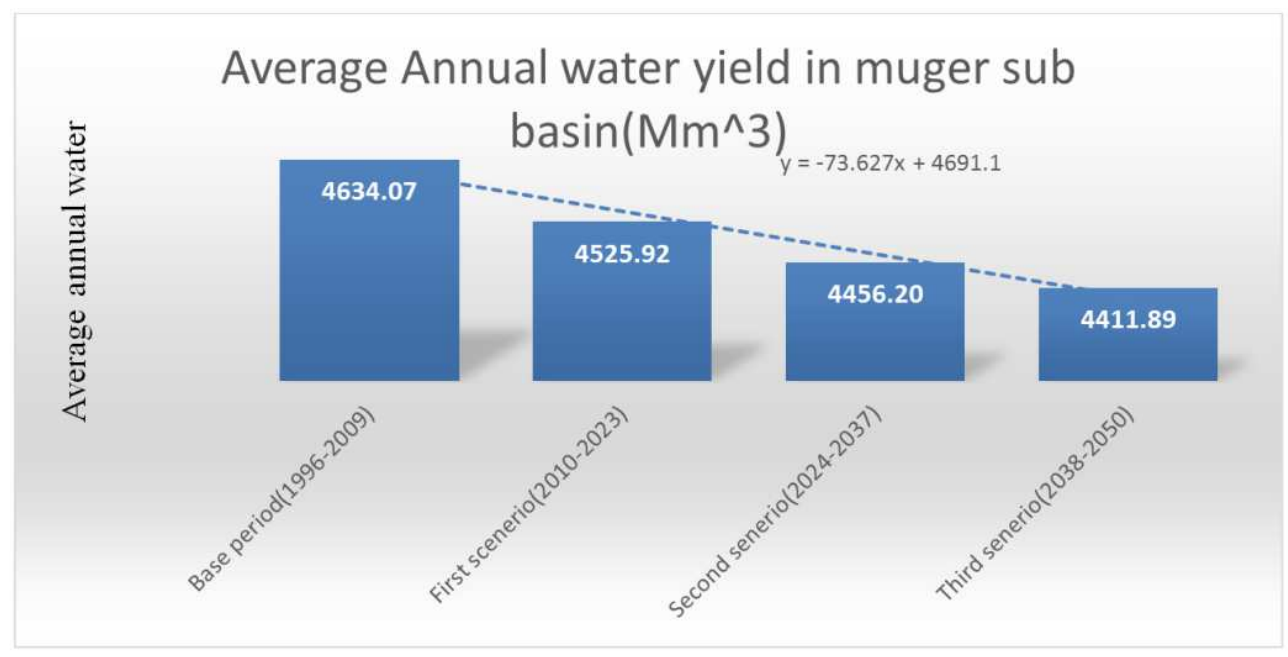

Figure 18. Mean annual water yield change due to climate change. 
The effect of climate change on average annual water yield of Muger sub-basin shown that water yield volume will decrease due to climate change of the (2010-2023), (20242037), and (2038-2050) from the baseline period (19962009 ) by $2.33 \%, 3.84 \%$, and $4.79 \%$ respectively.

\section{Conclusion}

The main aim of this research is Assessment of Surface Water Resources in Case of Muger Sub Basin in Ethiopia

Water resources play a crucial role in the economic development of the developing countries with ample of water resources like Ethiopia. The region's explosive population growth and resulting new demands on limited water resources require efficient management of existing water resources and building new facilities to meet the challenge. In water resources management system, it is well known that to combat water shortage issues, maximizing water management efficiency based on surface water assessement is crucial. Surface water assessement is vital importance to flood mitigation and water resources management and planning. While short- term forecasting such as hourly or daily forecasting is crucial for flood warning and defense, long-term forecasting based on monthly, seasonal or annual time scales is very useful in Water allocation to different activities, allocating water to downstream users, drought mitigation and managing river treaties or implementing compact compliance. But such studies under different condition and different period were not done in this subbasin, therefore this research focus on surface water assessement under different impact of climate change.

The future possible local climate variables are extracted from Abbay basin RCM and then the bias-corrected with observed meteorological variables which are then used as input to the soil and water assessment tool (SWAT) model as climate data, in addition to climate data soil data, land use land cover, slope of the sub basin and weather Generator together are used to simulate future water yield of Muger sub-basin. Soil and Water Assessment Tool (SWAT) was adopted to perform runoff simulation

Sequential Uncertainty Fitting version 2 (SUFI-2) was utilized for uncertainty analysis. SUFI-2 is linked with SWAT in the Calibration and Uncertainty Program known as SWATCUP.

The good performance of the SWAT model was confirmed, with a Nash-Sutcliffe efficiency (NSE) and determination coefficients $\left(\mathrm{R}^{2}\right)$ of 0.76 and 0.99 respectively during calibration for monthly runoff, Nash-Sutcliffe efficiency (NSE) 0.63 and determination coefficients $\left(\mathrm{R}^{2}\right) \quad 0.99$ respectively during validation for monthly runoff.

From this study, it was observed that due to climate change Average annual water yield in Muger sub-basin in (199620090), (2010-2023), (2024-2037), (2038-2050) is 4634.07 $\mathrm{Mm}^{3}, 4525.92 \mathrm{Mm}^{3}, 4456.20 \mathrm{Mm}^{3}$ and $4411.89 \mathrm{Mm}^{3}$ respectively, which indicate average annual water yield of Muger sub-basin that water yield volume will decrease due to climate change of the (2010-2023), (2024-2037), and (20382050) from the baseline period (1996-2009) by $2.33 \%$, $3.84 \%$, and $4.79 \%$ respectively. From the research finding, it was observed that the maximum and minimum temperature of the sub-basin increased while the precipitation decreased during the study period which is the main cause of a decrease in average water yield in the study area when temperature increase evaporation is increase which is inversely proportional to soil moisture content.

\section{References}

[1] Abayneh, A. (2011). Evaluation of Climate Change Impact on Extreme Evaluation of Climate Change Impact on Extreme Hydrological Event Addis Ababa University. Addis Ababa.

[2] Africa Climate Change Resilience Alliance (ACCRA). 2011. Climate Trends in Ethiopia.

[3] Awulachew, S. B. ((2008). Impact of watershed interventions on runoff and sedimentation in Gumera watershed. Arba Minch University, Ethiopia Research Service and Texas A.

[4] Conway, D., 2005: From headwater tributaries to international river: Observing and adapting to climate variability and change in the Nile basin. Global Environmental Change, 15, 99-114.

[5] Dibike, Y. B. and Coulibaly, P., 2005: Hydrologic impact of climate change in the Saguenay Watershed, comparison of downscaling methods and hydrologic models, J. Hydrol., 307 $(1-4)$.

[6] Hargreaves, G. H. \& Samani, Z. A. (1982). Estimating Potential Evapotranspiration. Journal of Irrigation and Drainage Division, 108 (3), 225-230.

[7] IPCC (Intergovernmental Panel on Climate Change), 2007: Climate Change 2007: Impacts, Adaptation, and Vulnerability - Contribution of Working Group II to the Third Assessment Report of the Intergovernmental Panel on Climate Change, edited by M. L. Parry et al Cambridge Univ. Press, Cambridge, U.K.

[8] Intergovernmental Panel on Climate Change (IPCC). 2013. Climate Change 2013: The physical Science Basis Contribution of Working Group I to the Fifth Assessment Report of the Intergovernmental Panel on Climate Change. Stocker, T. F., D. Qin, G-K. Plattner, M. Tignor, S. K. Allen, J. Boschung, A. Nauels, Y. Xia V. Bex and P. M. Nidgeley (eds.). Cambridge University Press, Cambridge, United Kingdom and New York, NY, USA, 1535 pp.

[9] Jensen, M. E., Burman, R. D. \& Allen, R. G. (1990). Evapotranspiration and irrigation water requirements. ASCE manuals and reports on engineering practice No. 70, ASCE, New York.

[10] Kim U, J. J Kaluarachchi, \& V. U Smakhtin, 2008: Climate Change Impacts on Hydrology and Water Resources of the Upper Blue Nile Basin, Ethiopia, IWMI RR 126.

[11] Kim, U., and J. J. Kaluarachchi 2009, Climate Change Impacts on Water Resources in the Upper Blue Nile River Basin, Ethiopia. Journal of the American Water Resources Association (JAWRA) 45 (6), 1361-1378. 
[12] Minichil. J. (2012). Evaluation of land use land cover change on Streamflow. a case study of dedissa sub-basin, abay basin, southwestern Ethiopia, Ariba Minch University.

[13] NMSA. (2001). National Meteorological Service Agency. Initial National Communication of Ethiopia to the United Nations Framework Convention on Climate Change.

[14] Neitsch, S. A. (2005). Soil and Water Assessment Tool, Theoretical documentation: Version.

[15] Neitsch S. L., J. G. Arnold, J. R. Kiniry, J. R. Williams, 2005:
Soil and Water Assessment Tool (SWAT) Input/output File Documentation, Version 2005, Grassland Soil and Water Research Laboratory, Agricultural Research Service, Blackland Research Center, Texas Agricultural Experiment Station.

[16] Ravazzani, G., Corbari, C., Morella, S., Gianoli, P. \& Mancini, M. (2011). Modified Hargreaves-Samani equation for the assessment reference evapotranspiration in Alphine river basin. Journal of irrigation and drainage engineering, 138 (7), 592-599. 